\title{
The Influence of Adolescent-Parent Career Congruence and Counselor Roles in Vocational Guidance on the Career Orientation of Students
}

\section{Bambang Suryadi}

Faculty of Psychology, Universitas Islam Negeri (UIN) Syarif Hidayatullah Jakarta, Indonesia, bambang.suryadi@uinjkt.ac.id

Dian Ratna Sawitri

Faculty of Psychology, Universitas Diponegoro Semarang, Indonesia, dian.r.sawitri@gmail.com

\section{Bahrul Hayat}

Faculty of Psychology, Universitas Islam Negeri (UIN) Syarif Hidayatullah Jakarta, Indonesia, muhammad.dwirifqi@mail.ugm.ac.id

\section{Dwirifqi Kharisma Putra}

Faculty of Psychology, Universitas Islam Negeri (UIN) Syarif Hidayatullah Jakarta, Indonesia,dwirifqi@icloud.com

Career orientation plays an important role in determining a student's future employment status. However, little is known about the extent to which parent and counselor roles influence the career orientation of their students or children. This study examines the influence of adolescent-parent career congruence and the role of guidance counselors in career orientation. The Adolescent-Parent Career Congruence Scale, Counselor Role in Vocational Guidance Scale, and Career Orientation Inventory Scale were used for data collection. This study selected a sample of 278 students, aged 15-18 years old, using a purposive sampling technique. The participants all attended Senior Secondary School or Vocational High School in Jakarta, Indonesia. Multiple regression and Confirmatory Factor Analysis (CFA) were performed to analyze the data. The results of multiple regression analysis indicate that both adolescent-parent career congruence and role of guidance counselors have a significant positive correlation with student career orientation. This study has practical implications for school counselors who provide vocational guidance services to students.

Keywords: career orientation, career congruence, vocational guidance, employability, career, students

Citation: Suryadi, B., Sawitri, D. R., Hayat, B., \& Putra, M. D. K. (2020). The Influence of Adolescent-Parent Career Congruence and Counselor Roles in Vocational Guidance on the Career Orientation of Students. International Journal of Instruction, 13(2), 45-60. https://doi.org/10.29333/iji.2020.1324a 


\section{INTRODUCTION}

One of the essential vocational services in schools is career guidance, and school counselors play a significant role in its provision, to minimize career disorientation among students that may damage their future careers. Many studies have been conducted to assess career related perspectives, which include career aspirations (Rainey \& Borders, 1997), career orientation (Savickas, 1999), career maturity (Creed \& Patton, 2003), career adaptability (Eryilmaz \& Kara, 2017), career-related support (Michaeli, Dickson, \& Shulman, 2018), career feedback (Hu, Hood, \& Creed, 2018), career intention (Chan, Chen, Lin, Liao, \& Lin, 2018; Guan, Jiang, Wang, Mo, \& Zhu, 2017), career planning (Rogers \& Creed, 2011), career decision making (Leung, Hou, Gati, \& Li, 2011; Lewis, Raque-Bogdan, Lee, \& Rao, 2018; Mao, Hsu, \& Fang, 2017; Park Woo, Park, Kyea, \& Yang, 2017; Wolfe \& Betz, 2004), and career transitions (Cordeiro, Paixão, Lens, Lacante, \& Luyckx, 2018). This study focuses on career orientation. According to Coetzee and De Villiers (2010), career orientation is an individual's career self-concept, which involves their understanding of available careers, and the work lives of employees. Career orientation is crucial for students to determine their career plan, behavior, and subsequent outcomes (Ngo \& Hui, 2018).

Previous studies show that many psychological factors affect students' career orientation, such as career maturity (Creed \& Patton, 2003), work and goal orientations (Heslin, 2005), and self-efficacy (Chan et al., 2018). Having a clear understanding of the factors that affect students' career orientation is crucial for school counselors and parents. According to Suryadi (2010), school counselors play a significant role in identifying these psychological factors, and they have an obligation to provide career orientation services to students so they can meet the challenges of the work environment. A study by Young (1994) suggests that parents can also play an active role in helping their children with career development, however, parents and children need to be aware of each other's perspectives and intentions as they negotiate career options.

Recent studies in the area of vocational guidance indicate that unemployment is a trending topic. The unemployment rate in Indonesia is 5.3\% (Statistics Indonesia, 2017), which is marginally lower than the global unemployment rate of $5.5 \%$ (International Labor Organization, 2018). The Indonesian government is confident that its unemployment target of $4.0 \%-5.0 \%$ will be achieved in 2019 , as economic growth rises. The large national workforce of 133 million (Statistics Indonesia, 2017), has an enormous contribution potential for the future economy. A study by Rudy (2018) suggests that there are three main issues related to the workforce. First, $60 \%$ of Indonesia's workforce (Statistics Indonesia, 2018) is dominated by those educated to primary school level or below, and most of them are in the informal sector. Second, there is a mismatch of around 50\% between the competences of school graduates and industrial needs. Third, graduates from vocational high school and polytechnics still have a high unemployment rate of $25 \%$. 
In the Indonesian context, there are three vocational institutions: vocational high school (SMK), polytechnics, and the government's vocational educational training institutions (BLK). Nevertheless, they often do not focus on producing a high-level workforce. A road-map of employment development is urgently required as guidance for their functions and duties (Rudy, 2018). According to the Ministry of Education and Culture Republic of Indonesia (2015), there are 12,573 high schools throughout Indonesia, of which 6,292 are public, and 6,281 are private. There are 3,140,513 public high school students and 1,092,059 students in private schools. Indonesia has 12,421 SMKs, comprising 3,250 state schools and 9,171 private schools. The number of public vocational high school students is $1,748,338$, while the number of private vocational high school students is $2,462,907$. These numbers will continue to grow due to government policies aimed at increasing access to primary and secondary education.

According to Indonesian government policy, career guidance has been part of the national curriculum since 1975 . The necessity of providing vocational guidance for students is mentioned in the Ministry of Education and Culture's Regulation Number 111 (Ministry of Education and Culture Republic of Indonesia, 2014). According to this regulation, the ultimate objective of vocational guidance services is to facilitate students to develop, explore, and make informed career decisions.

Despite the vocational guidance services provided to students, the issue of unskilled employment and unemployment remains unresolved. A study by Reid (2010) found that unskilled employment and unemployment were the leading causes of poverty. Reid's (2010) findings suggest that the role of the career guidance counselor is not clearly defined. According to Statistics Indonesia, the rate of unemployment among senior secondary vocational school students in February 2017 was $9.27 \%$, and $7.03 \%$ for general secondary school students (Statistics Indonesia, 2017). This unemployment rate is a challenge for school counselors seeking to equip their students with the attitudes, knowledge, and skills required by employers (Suryadi, Sawitri, Hamidah, \& Hanifa, 2018).

The employability of school graduates is influenced by many factors, however a key factor is work attitudes. The results of a focused group discussion (Board for National Standard in Education, 2016), indicate that there are three aspects of competencies required by the business and industrial sectors: basic knowledge, technical skills, and positive work attitudes. Of these, a positive work attitude is the most important, because while basic knowledge and technical skills can be formed in a relatively short time, work attitude is a result of a persons' entire education experience.

The role of school counselors in providing career guidance services to students is another key factor influencing employability The Indonesian Young Workers' Market Survey, and the Impact of Dropping Out of School at Youth and Child Labor Survey (Indonesian Association for Guidance and Counseling, 2011) found that in Eastern Indonesia, $88 \%$ of respondents had not received career guidance, although they felt guidance would have been useful in finding work. The results highlighted one of the paradoxes in implementing career guidance in Indonesia; that although school counselors have facilitated the transition from the school world to the workforce, few 
have access to relevant career and educational guidance. Furthermore, the results of the study show that Indonesian youth wish to make decisions regarding their education and employment based on their aspirations and competencies, as well as demand from the labor market. However, students often do not receive optimal guidance and counseling services at school, and counselors are limited by the latest practical reference material for carrying out their duties.

A final key factor is adolescent-parent career congruence. Whiston and Keller (2004) found that families, especially parents, have a substantial effect on the career development of their teenage children. Dik and Duffy (2009) state that parents influence the development of their teenage children based on knowledge of their values, interests, and skills, and have an essential role in developing motivation and maintaining focus on achieving their career goals. Although the role of parents is significant for determining the career orientation of adolescents, several studies indicate a difference in views between parents and adolescents (Daddis \& Smetana, 2005; Feldman \& Wood, 1994; Zimmer-Gembeck, Ducat, \& Collins, 2011).

This study examines the influence of adolescent-parent career congruence and the role of counselors in vocational guidance on career orientation for Senior Secondary School and Vocational High School students in Jakarta, Indonesia. The findings of this study have practical implications for school counselors in improving the quality of career guidance services to students.

\section{METHOD}

\section{Research Design}

A descriptive quantitative research design was applied in this study. According to Mitchell and Jolley (2010), the primary purpose of the descriptive study is to accurately measure and record variables. Based on this, the research design and model are illustrated in Figure 1.

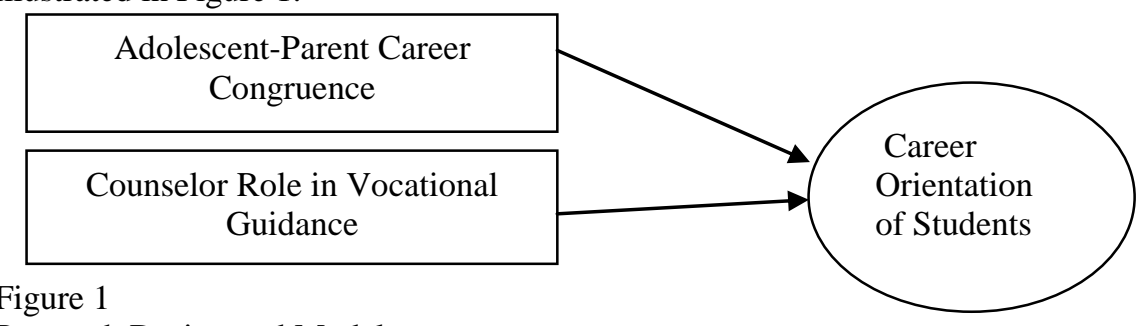

Research Design and Model

Figure 1 shows two independent variables (adolescent-parent career congruence and counselor role in vocational guidance) and one dependent variable (student career orientation) and their influences on dependent variable (career orientation of students).

\section{Research Hypotheses}

In this study, three hypotheses were tested. The major hypothesis $\left(\mathrm{H}_{0}\right)$ states that career congruence between adolescents and parents, and the role of counselors in career guidance, has no significant influence on career orientation of high school and 
vocational students. The first minor hypothesis $\left(\mathrm{H}_{1}\right)$ states that career congruence between adolescents and parents has a significant influence on the career orientation of high school and vocational students. The second minor hypothesis $\left(\mathrm{H}_{2}\right)$ states that the role of the counselor in career guidance has a significant influence on the career orientation of high school and vocational students.

\section{Participants}

A total of 278 grade 12 students, 94 males and 184 females, aged 15-18 years, took part in this study. Participants were selected from two Senior High Schools (SMA)and two Senior Vocational Schools (SMK) in Jakarta. The sample for this study was selected using a non-probability sampling technique. The distribution of the sample size based on school, gender, age, and study program, is presented in Table 1.

Table 1

Sample Size Based on School, Gender, Age, and Study Program

\begin{tabular}{lll}
\hline School & Frequencies & $\%$ \\
\hline SMA & 125 & 45 \\
SMK & 153 & 55 \\
Total & 278 & 100 \\
\hline Gender & & \\
\hline Boys & 94 & 34 \\
Girls & 184 & 66 \\
Total & 278 & 100 \\
\hline Age & & \\
\hline 15 years & 1 & 0.3 \\
16 years & 12 & 4.3 \\
17 years & 203 & 73 \\
18 years & 62 & 22.4 \\
Total & 278 & 100 \\
\hline Study Program & & \\
\hline Culinary & 47 & 16.9 \\
Dance & 14 & 5 \\
Office Administration & 34 & 12.2 \\
Accountancy & 58 & 20.9 \\
Natural Sciences & 62 & 22.3 \\
Social Sciences & 63 & 22.7 \\
Total & 278 & 100 \\
\hline
\end{tabular}

Limitations of the sample include a higher number of SMK (55\%) respondents than SMA respondents $(45 \%)$, and a high proportion of female respondents $(66 \%)$. The data also shows that the majority of respondents $(73 \%)$ are 17 years old.

\section{Instruments}

Three types of instruments were used in this study. First, the Adolescent-Parent Career Congruence Scale(APCC), which was adapted from the work of Sawitri, Creed, and Zimmer-Gembeck (2013). The APCC has 12 items designed to describe two domains of congruence: seven complementary congruence items, describing needs-supplies and 
demands-abilities congruence;), and five supplementary congruence items, describing the similarity of adolescent and parents. An example of a statement that measures complementary congruence is, "My parents encourage me to explore the career areas I am interested in" (Item 1). An example of statement that measures supplementary congruence is, "My parents want the same career for me as I want for myself" (Item 9).

The second instrument, the Counselor Role in Vocational Guidance (CRVG), was adapted from the work of Suryadi (2010). The CRVG has nine items measuring the role of the counselor in providing vocational guidance for students. An example of a statement that expresses the counselor's role and function in vocational guidance is, "Counselor conducts a class size of large group workshop for students to help them develop resume writing, interview, and job seeking skills" (Item 2).

The third instrument applied in this study was the Student Career Orientation (SCO), adapted from the work of Schein (1990). The SCO has 40 items measuring autonomy/independence, security/stability, lifestyle, technical/functional capability, general managerial competence, entrepreneurial creativity, service or dedication to a cause, and real challenges. An example of a statement that measures autonomy/independence is, "I dream of having a career that will allow me the freedom to do a job my way and on my schedule" (Item 3).

The respondents were required to respond to each item using a Likert-type format, with options ranging from 1 (strongly disagree) to 4 (strongly agree). The original instruments were translated from English to Indonesian to suit the participants. The English version of the questionnaire is provided in the Appendices.

\section{Procedure}

During the administration of the questionnaires, instructions were clearly explained to the respondents. The purpose of the questionnaires was made clear in order to eliminate potential resistance and encourage participants to complete the questionnaires. The respondents were informed that all the information they provided would be kept confidential.

The respondents were also informed that the results of the study would be made available to the schools and that the findings of this study could be beneficial for improving school guidance services in the future. Questionnaires were administered to the respondents with the assistance of classroom teachers. Each questionnaire took 20 minutes to complete. Demographic data on age, gender, and study program was also collected.

The data were analyzed using multiple regression and variance analysis, using three variables: (1) the percentage of the variance of the dependent variable, caused by the independent variable; (2) whether the overall independent variables significantly influence the dependent variable; and (3) the significance of the regression coefficients of each independent variable.

\section{Data Analysis}

Descriptive statistics, such as frequency and percentage, were used to present the respondents' demographic data (Table 1). Confirmatory Factor Analysis (CFA), using 
Mplus 8.2 (Muthen \& Muthen, 1998-2017), was carried out to analyze the construct validity of the research instruments. Multiple regression, using SPSS version 17.0 software, was applied to examine the influence of the two independent variables on the dependent variable. The two independent variables investigated were adolescent-parent career congruence and the counselor's role in vocational guidance, while the dependent variable was the student career orientation.

\section{FINDINGS}

Analysis of the R-square magnitude was used to determine the percentage variance of the dependent variable, as caused by the independent variable (see Table 2).

Table 2

Model Summary of Regression Analysis

\begin{tabular}{lllll}
\hline \multicolumn{3}{l}{ Model Summary } & & \\
Model & $\mathrm{R}$ & $\mathrm{R}$ Square & Adjusted R Square & $\begin{array}{l}\text { Std. The error of the } \\
\text { Estimate }\end{array}$ \\
\hline 1 & $.450^{\mathrm{a}}$ & .203 & .197 & 8.50255 \\
\hline a. Predictors: Adolescent-Parent Career Congruence, Counselor Role
\end{tabular}

The R-square value is 0.203 , or $20.3 \%$, suggesting that the contribution of two independent variables evaluated as part of this study is $20.3 \%$, while the other $79.7 \%$ is determined by other variables. These other variables can be internal or external factors. Among internal variables are self-concept, career stability, and resilience, while among external variables are peer influence and school academic climate.

Independent variables were then analyzed to determine if they had a significant influence on the dependent variable, using the F test.

Table 3

Analysis of Variance for the Influence of All the Independent Variable on the Dependent Variable

\begin{tabular}{lllllll}
\hline \multicolumn{2}{c}{ ANOVA } & & & & & \\
\hline Model & & Sum of Squares & df & Mean Square & F & Sig. \\
\hline \multirow{3}{*}{1} & Regression & 5052.250 & 2 & 2526.125 & 34.943 & $.000^{\mathrm{b}}$ \\
\cline { 2 - 8 } & Residual & 19880.674 & 275 & 72.293 & & \\
\cline { 2 - 7 } & Total & 24932.924 & 277 & & & \\
\hline
\end{tabular}

a. Dependent Variable: Career Orientation

b. Predictors: Adolescent-Parent Career Congruence, Counselor Role

Table 3 shows that the significance value is $0.000(\mathrm{p}<0.05)$; this indicates that the major hypothesis, which stated that career congruence between adolescents and parents, and the role of counselors in career guidance, has no significant influence on career orientation of high school and vocational students, is rejected. Therefore, it is clear that adolescent-parent career congruence and counselor roles significantly affect students' career orientation.

Finally, the regression coefficients of each independent variable were assessed, with a significance value of $<0.05$, indicating that the independent variables have a significant 
impact on career orientation. The variables that influence the dependent variable are shown in Table 4.

Table 4

Coefficient Regression of Each Independent Variable

\begin{tabular}{|c|c|c|c|c|c|c|}
\hline & Coefficients & & & & & \\
\hline \multirow{2}{*}{ Model } & & \multicolumn{2}{|c|}{$\begin{array}{l}\text { Unstandardized } \\
\text { Coefficients }\end{array}$} & $\begin{array}{l}\text { Standardized } \\
\text { Coefficients }\end{array}$ & \multirow[t]{2}{*}{$\mathrm{t}$} & \multirow{2}{*}{ Sig. } \\
\hline & & $\mathrm{B}$ & Std. Error & Beta & & \\
\hline \multirow[t]{3}{*}{1} & (Constant) & 20.776 & 3.536 & & 5.876 & .000 \\
\hline & $\begin{array}{l}\text { Adolescent-Parent } \\
\text { Career Congruence }\end{array}$ & .271 & .055 & .271 & 4.937 & .000 \\
\hline & Counselor role & .314 & .056 & .308 & 5.611 & .000 \\
\hline
\end{tabular}

a. Dependent Variable: Career Orientation

For the first independent variable, adolescent-parent career congruence, the results showed a regression coefficient value of 0.27 , with a significance of $0.000(\mathrm{p}<0.05)$; thus $\mathrm{H}_{0}$, which states that there is no influence from the adolescent parent career congruence to the career orientation, is rejected. That is, the adolescent parent career congruence has a significant influence on career orientation. A positive regression coefficient indicates a positive relationship between adolescent-parent career congruence and career orientation.

Results for the second independent variable, the role of the councilor found a regression coefficient value of 0.314 with a significance equal to 0.000 ( $\mathrm{p}<0.05)$; also rejecting $\mathrm{H}_{0}$, and indicating that the role of the counselor has a significant influence on career orientation.

In order to understand which regression coefficient has a stronger influence on students' career orientation, a standardized coefficient, or beta $(\beta)$, was used. The results determined that the counselor role has a more significant influence than adolescentparent career congruence, with a higher beta $(\beta)$ value of 0.308 .

An analysis was then undertaken to examine the variance proportion from each independent variable and its influence on the dependent variable. The results are presented in Table 5.

Table 5

Variance Proportion from Each Independent Variable and its Influence on the Dependent Variable

\begin{tabular}{llllllll}
\hline \multicolumn{1}{c}{ Model Summary } \\
\hline \multirow{2}{*}{ Model } & $\mathrm{R}$ & R Square & $\begin{array}{l}\text { Change Statistics } \\
\text { R Square } \\
\text { Change }\end{array}$ & F Change & df1 & df2 & $\begin{array}{l}\text { Sig. F } \\
\text { Change }\end{array}$ \\
\hline 1 & $.334^{\mathrm{a}}$ & .111 & .111 & 34.579 & 1 & 276 & .000 \\
2 & $.450^{\mathrm{b}}$ & .203 & .091 & 31.487 & 1 & 275 & .000 \\
\hline
\end{tabular}

Results in Table 5 indicate that adolescent-parent career congruence contributed $11.1 \%$ to the variance in career orientation, while the counselor role contributed $9.1 \%$. 


\section{DISCUSSION}

The results of this study indicate that parent-adolescent career congruence and the career counselor role has a significant effect on the career orientation of adolescents. These findings suggest that when a student's career orientation aligns with the wishes of their parents, they tend to be more confident with the career choices they will make after graduating from school, improving their prospects of finding employment.

The results are consistent with two previous studies (Dietrich \& Kracke, 2009; Dik \& Duffy, 2009), which indicated that parents have a significant influence on their children's values, interests, and skills, and have an essential role to play in developing their child's work attitude, and motivation, to achieve career goals. Recent research conducted by Sawitri, Creed, \& Zimmer-Gembeck (2014) concluded that parental career expectations, values, and support are the dominant factors in the process of developing adolescents' career choices. Students who have career choices in line with their parents' expectations are better enabled to make an appropriate career choice.

Data from the Central Statistics Agency (BPS, 2017) indicates that the unemployment rate for graduates of SMKs is slightly higher than that from SMAs, at $9.27 \%$ and $7.03 \%$, respectively. The high level of unemployment in vocational high school graduates illustrates that their career orientation, and the role of career guidance given by counselors at school, is not optimal. Sibgatova et al. (2015) noted that school counselors need to develop professional skills and competencies to assist students with career guidance, in the context of a rapidly changing labor market. Suryadi's (2018) study found that most high school or vocational school graduates lack information about the world of work and careers. When asked about careers, students indicated that they were still confused as to whether they should find work, or continue their studies. The challenge is for students to develop themselves in a sufficiently rounded way to become employable (Ponge, 2013), however, it is the responsibility of schools to facilitate and nurture students to improve their chance of finding suitable employment after they graduate.

Furthermore, the results of this study indicate that students given a higher level of career guidance, have a stronger career orientation. Suryadi (2010) suggests that school counselors are responsible for providing vocational guidance to students, such as information about career choices and job opportunities. If school counselors do not perform well in providing such vocational guidance, students may be unable to fully develop their career goals.

The findings of this study support a previous study that indicated career competencies positively contribute to learning motivation, quality of study choice, a better fit with learning tasks, and more successful internships (Meijers, Kuijpers, \& Gundy, 2013). The findings further indicated that career dialogue contributed more to successful career outcomes than traditional interventions.

The results of this study indicate a need for school counselors to be provided with career development programs. The school counselor has a vital role in providing guidance in career orientation. School counselors should be able to provide career choice 
information and consultation sessions with students who are still in doubt about their career choices.

This study has practical implications for school counselors and teachers in improving the quality of graduate's competencies. It confirms that vocational guidance programs are an integral part of the overall education program, and therefore, suggests that learning materials could be designed according to a student's future career preferences.

This study has potential limitations. First, only two independent variables, adolescentparent career congruence and the counselor role, were analyzed. Other potential variables were not assessed and should be considered in future research. Second, the respondents of this study were selected from both senior vocational schools and senior general schools, however, polytechnic students and Center for Labor Training students were not included. Finally, the research was limited to the City of Jakarta. Future research could resolve these limitations by analyzing a broader range of variables and including students from a broader range of institutions. Future research may also consider participants from cities outside Jakarta, to provide a broader national perspective on students' career orientations.

\section{CONCLUSION}

This study found that school counselors and parents have a significant effect on the career orientation of students. The results indicate that while both variables are significant, the role of student counselors was found to be more significant, supporting the recommendation that school counselors should undertake professional development, and course material should be developed to support career guidance. The results are also limited by the use of two variables, which account for only $20 \%$ of the factors affecting career orientation; therefore additional research is recommended.

\section{REFERENCES}

Board for National Standard in Education. (2016). Focused group discussion on competencies needed by industrial sectors (Unpublished annual report). Jakarta, Indonesia: Board for National Standard in the Education Republic of Indonesia.

Chan, C.-C., Chen, S.-C., Lin, Y.-W., Liao, T.-Y., \& Lin, Y.-E. (2018). Social cognitive perspective on factors influencing Taiwanese sport management students' career intentions. Journal of Career Development, 45(3), 239-252. https://doi.org/10.1177/0894845316681643.

Coetzee, M., \& De Villiers, M. (2010). Sources of job stress, work engagement and career orientations of employees in a South African financial institution. SA Business Review, 14(1), 27-57.

Cordeiro, P. M. G., Paixão, M. P., Lens, W., Lacante, M., \& Luyckx, K. (2018). Parenting styles, identity development, and adjustment in career transitions: The mediating role of psychological needs. Journal of Career Development, 45(1), 83-97. https://doi.org/10.1177/0894845316672742. 
Creed, P. A., \& Patton, W. (2003). Predicting two components of career maturity in school-based adolescents. Journal of Career Development, 29(4), 277-290 https://link.springer.com/article/10.1023/A:1022943613644.

Daddis, C., \& Smetana, J. (2005). Middle-class African American families' expectations for adolescents' behavioral autonomy. International Journal of Behavioral Development, 29(5), 371-381. https://doi.org/10.1177/01650250500167053.

Dietrich, J., \& Kracke, B. (2009). Career-specific parental behaviors in adolescents' development. Journal of Vocational Behavior, 75(2), 109-119. https://doi.org/10.1016/j.jvb.2009.03.005.

Dik, B. J., \& Duffy, R. D. (2009). Calling and vocation at work: Definitions and prospects for research and practice. The Counseling Psychologist, 37(3), 424-450. http://dx.doi.org/10.1177/0011000008316430.

Eryilmaz, A., \& Kara, A. (2017). Comparison of teachers and pre-service teachers with respect to personality traits and career adaptability. International Journal of Instruction, 10(1), 85-100. https://doi.org/10.12973/iji.2017.1016a.

Feldman, S. S., \& Wood, D. N. (1994). Parents' expectations for preadolescent sons' behavioral autonomy: A longitudinal study of correlates and outcomes. Journal of Research on Adolescence, 4(1), 45-70. http://dx.doi.org/10.1207/s15327795jra0401_4.

Furr, R. M., \& Bacharach, V. R. (2013). Psychometrics: An introduction. Thousand Oaks, CA: Sage.

Guan, Y., Jiang, P., Wang, Z., Mo, Z., \& Zhu, F. (2017). Self-referent and other-referent career successes, career satisfaction, and turnover intention among Chinese employees: the role of achievement motivation. Journal of Career Development, 44(5), 379-393. https://doi.org/10.1177/0894845316657181.

Heslin, P. A. (2005). Conceptualizing and evaluating career success. Journal of Organizational Behavior, 26(2), 113-136. https://doi.org/10.1002/job.270.

Hu, S., Hood, M., \& Creed, P. A. (2018). Career goal importance as a moderator in the relationship between career feedback and career-related stress. Journal of Career Development, 45(1), 3-18. https://doi.org/10.1177/0894845316667847.

Indonesian Association fo Guidance and Counseling (ABKIN) and Jakarta International Labor Organization. (2011). Panduan Pelayanan Bimbingan Karir Bagi Guru Bimbingan Konseling/Konselor pada Satuan Pendidikan Dasar dan Menengah. Organisasi Perburuhan Internasional: Jakarta.

International Labor Organization. (2018). Statistics and databases. International labor organization. Retrieved from https://www.ilo.org/global/statistics-and-databases/lang-en/index.htm. 
Kuijpers, M. A. C. T., \& Scheerens, J. (2006). Career competencies for the modern career. Journal of Career Development, 32(4), 303-319. https://doi.org/10.1177/ 0894845305283006 .

Leung, S. A., Hou, Z.-J., Gati, I., \& Li, X. (2011). Effects of parental expectations and cultural-values orientation on career decision-making difficulties of Chinese University students. Journal of Vocational Behavior, 78(1), 11-20. https://doi.org/10.1016/j.jvb.2010.08.004.

Lewis, J. A., Raque-Bogdan, T. L., Lee, S., \& Rao, M. A. (2018). Examining the role of ethnic identity and meaning in life on career decision-making self-efficacy. Journal of Career Development, 45(1), 68-82. https://doi.org/10.1177/0894845317696803.

Mao, C.-H., Hsu, Y.-C., \& Fang, T.-W. (2017). Mediating effect of career decision selfefficacy on the relationship between parental support and indecision in Taiwan. Journal of Career Development, 44(6), 471-484. https://doi.org/10.1177/0894845316663319.

Meijers, F., Kuijpers, M., \& Gundy, C. (2013). The relationship between career competencies, career identity, motivation and quality of choice. International Journal for Educational and Vocational Guidance, 13(1), 47-66. https://doi.org/10.1007/s10775-012-9237-4.

Michaeli, Y., Dickson, D. J., \& Shulman, S. (2018). Parental and nonparental careerrelated support among young adults: antecedents and psychosocial correlates. Journal of Career Development, 45(2), 150-165. https: //doi.org/10.1177/0894845316671428.

Ministry of Education and Culture Republic of Indonesia. (2014). Peraturan menteri pendidikan dan kebudayaan nomor 111 tahun 2014 tentang bimbingan dan konseling pada pendidikan dasar dan pendidikan menengah. Jakarta, Indonesia: Ministry of Education and Culture Republic of Indonesia.

Ministry of Education and Culture Republic of Indonesia. (2015). Data pokok pendidikan dasar dan menengah. Jakarta, Indonesia: Ministry of Education and Culture Republic of Indonesia.

Mitchell, M. L., \& Jolley, J. M. (2010). Research design explained. Belmont, CA: Wadsworth Cengage Learning.

Muthén, L. K., \& Muthén, B. O. (1998-2017). Mplus user's guide: Statistical analysis with latent variables. Los Angeles, CA: Muthén \& Muthén.

Ngo, H.-Y., \& Hui, L. (2018). Individual orientations and career satisfaction: the mediating roles of work engagement and self-efficacy. Journal of Career Development, 45(5), 425-439. https://doi.org/10.1177/0894845317706759.

Park, K., Woo, S., Park, K., Kyea, J., \& Yang, E. (2017). The mediation effects of career exploration on the relationship between trait anxiety and career indecision. Journal of Career Development, 44(5), 440-452. https://doi.org/10.1177/0894845316662346. 
Ponge, A. (2013). Graduate unemployment and unemployability in Kenya: Transforming university education to cope with market demands and the lessons for Africa. International Journal of Social Science Tomorrow, 2(3), 1-12.

Rainey, L. M., \& Borders, L. D. (1997). Influential factors in career orientation and career aspiration of early adolescent girls. Journal of Counseling Psychology, 44(2), 160. http://dx.doi.org/10.1037/0022-0167.44.2.160.

Reid, H. L. (2010). Supervision to enhance educational and vocational guidance practice: a review. International Journal for Educational and Vocational Guidance, 10(3), 191-205. https://doi.org/10.1007/s10775-010-9184-x.

Rogers, M. E., \& Creed, P. A. (2011). A longitudinal examination of adolescent career planning and exploration using a social cognitive career theory framework. Journal of Adolescence, 34(1), 163-172. https://doi.org/10.1016/j.adolescence.2009.12.010.

Rudy, S. (2018). Innovation in governance to enhance competency in the future. Paper presented at the 4th ASEAN+3 HRD FORUM Digital Economy and Shared Future: Innovation, Policy, and Governance in Skills Development, Jeju Island, South Korea.

Savickas, M. L. (1999). The transition from school to work: A developmental perspective. The Career Development Quarterly, 47(4), 326-336. http://dx.doi.org/10.1002/j.2161-0045.1999.tb00741.x.

Sawitri, D. R., Creed, P. A., \& Zimmer-Gembeck, M. J. (2014). Parental influences and adolescent career behaviours in a collectivist cultural setting. International Journal for Educational and Vocational Guidance, 14(2), 161-180. https://doi.org/10.1007/s10775013-9247-x.

Schein, E. H. (1996). Career anchors revisited. Implications for career development in the 21st century. Academy of Management Executive, 10(4), 80-88.

Sibgatova, K. I., Sabirov, I. T., Sadovaya, V. V., Vlasova, V. K., Leyfa, I. I., Yatsevich, L. P., \& Fassakhova, G. R. (2015). Pedagogical potential of the career guidance course "professional career planning" to form pupils and students' self-determination in the integrated system "school-vocational college". Review of European Studies, 7(1), 8085. https://doi.org/10.5539/res.v7n1p80.

Statistics Indonesia. (2017). Berita resmi statistik: keadaan ketenagakerjaan Indonesia februari 2017. No. 47/05/Th.XX,05 Mei 2017.3. Jakarta, Indonesia: Statistics Indonesia.

Suryadi, B. (2010). The role of public senior secondary school counselors in East Java: Students', teachers', and counselors' perceptions. Germany: VDM Verlag Dr. Muller Aktiengesellschaft \& Co. KG and Licensors.

Suryadi, B., Sawitri, D. R., Hamidah, \& Hanifa, F. (2018). Career orientation of senior secondary school students. SHS Web of Conferences, 42, 00005. https://doi.org/10.1051/shsconf/20184200005. 
Whiston, S. C., \& Keller, B. K. (2004). The influences of the family of origin on career development: A review and analysis. The Counseling Psychologist, 32(4), 493-568. https://doi.org/10.1177/0011000004265660.

Wolfe, J. B., \& Betz, N. E. (2004). The relationship of attachment variables to career decision-making self-efficacy and fear of commitment. The Career Development Quarterly, 52(4), 363-369. https://doi.org/10.1002/j.2161-0045.2004.tb00952.x.

Young, R. A. (1994). Helping adolescents with career development: the active role of parents. The Career Development Quarterly, 42(3), 195-203. https://doi.org/10.1002/j.2161-0045.1994.tb00934.x.

Zimmer-Gembeck, M. J., Ducat, W., \& Collins, W. A. (2011). Autonomy development during adolescence. In B. B. Brown \& M. Prinstein (Eds.), Encyclopedia of adolescence (pp. 66-76). New York, NY: Academic Press.

\section{APPENDICES}

\section{Questionnaire on Adolescent-Parent Career Congruence Scale}

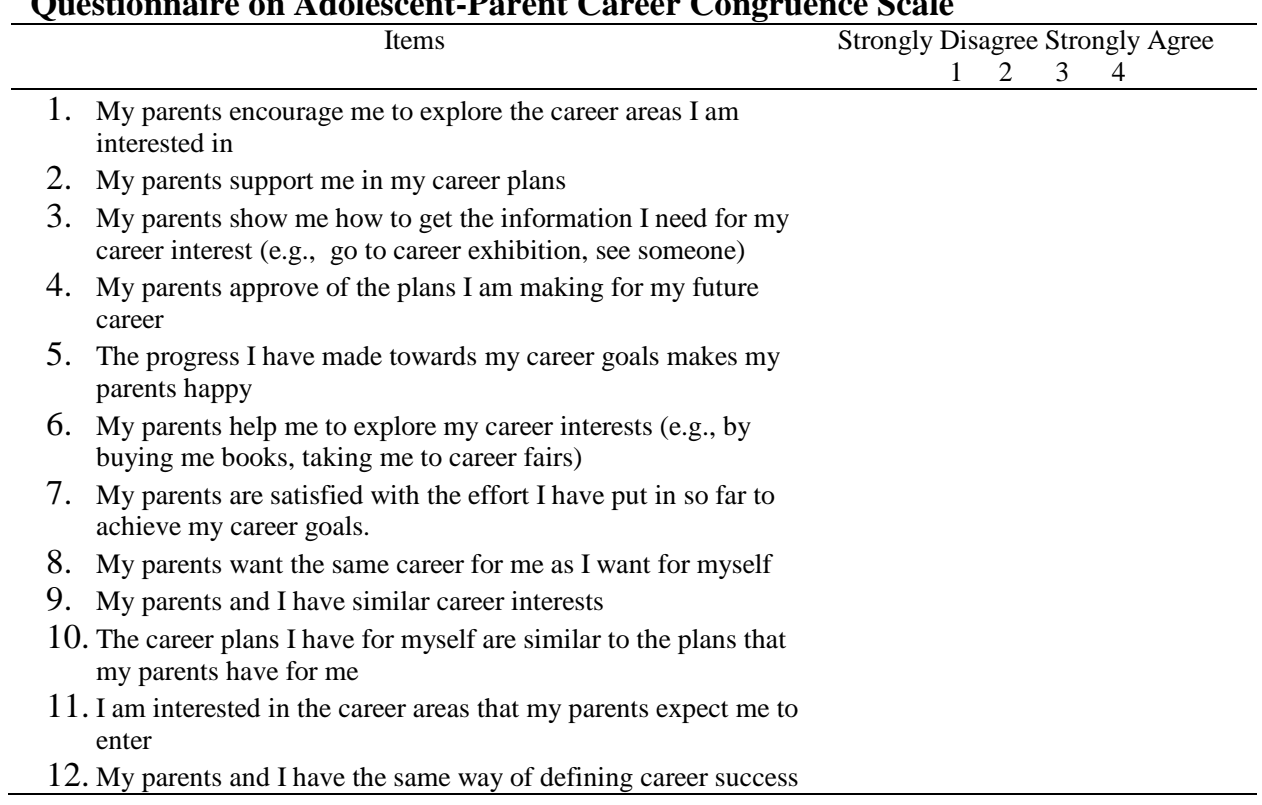

\section{Questionnaire on Counselor Roles in Vocational Guidance Scale}

Items

1. Counselor meets with individual students to discuss career information and/or to help students in career planning

2. Counselor conducts a class size of large group workshop for students to help them develop resume writing, interview, and job seeking skills.

3. Counselor assists student to seek employment (part-time or full- 
time employment).

4. Counselor administers to an individual or a class size or a large group of students a career inventory to assess students' career potential

5. Counselor consults with community agencies (education department, social services department) about job vacancies.

6. Counselor plans activities (discussion, field trip) to stimulate interest in the world of work.

7. Counselor provides vocational information to students wishing to explore career.

8. Counselor helps students relate their abilities to future career choices.

9. Counselor provides information on the qualifications needed for jobs.

\section{Questionnaire on Career Orientation Scale}

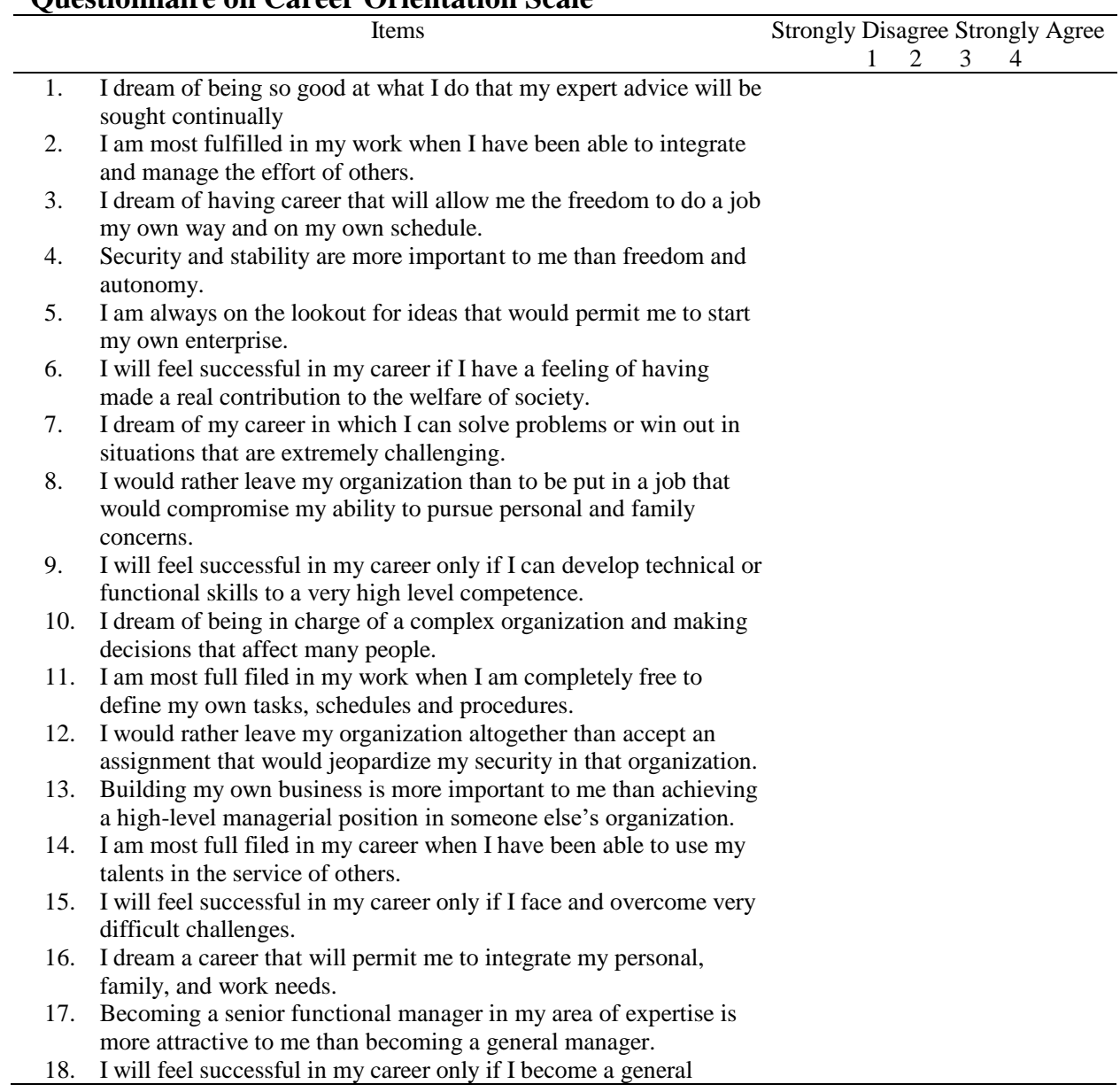

International Journal of Instruction, April $2020 \bullet$ Vol.13, No.2 
manager in some organization.

19. I will feel successful in my career only if I achieve complete autonomy and freedom.

20. I seek job in organizations that will give me a sense of security and stability.

21. I am most fulfilled in my career when I have been able to build something that is entirely the result of my own ideas and efforts.

22. Using my skills to make the world a better place to live and work is more important to me than achieving a high-level managerial position.

23. I have been most fulfilled in my career when I have solved seemingly unsolvable problems or won out over seemingly impossible odds.

24. I feel successful in life only if I have been able to balance my personal, family, and career requirements.

25. I would rather leave my organization than accept a rotational assignments what would take me out of my area of expertise.

26. Becoming a general manager is more attractive to me than becoming a senior functional manager in my current area of expertise.

27. The chance to do a job my own way, free of rules and constraints, is more important to me than security.

28. I am most fulfilled in my work when I feel that I have complete financial and employment security.

29. I will feel successful in my career only if I succeed in creating or building something that is entirely my own product or idea.

30. I dream of having a career that makes a real contribution to humanity and society.

31. I seek out work opportunities that strongly challenge my problem solving and/or competitive skills.

32. Balancing the demands of personal and professional life is more important to me than achieving a high-level managerial position.

33. I am most fulfilled in my work when I have been able to use my special skills and talents.

34. I would rather leave my organization that accept a job that would take me away from the general managerial track.

35. I would rather leave my organization that accept a job that would reduce my autonomy and freedom.

36. I dream of having a career that will allow me to feel a sense of security and stability.

37. I dream of starting up and building my own business.

38. I would rather leave y organization than accept an assignment that would undermine my ability to be of service to others.

39. Working on problems that are almost unsolvable is more important to me than achieving a high-level managerial position.

40. I have always sought out work opportunities that minimize interference with personal or family concerns.

International Journal of Instruction, April $2020 \bullet$ Vol.13, No.2 